\title{
Comparison of Five Detection and Quantification Methods for Phytophthora ramorum in Stream and Irrigation Water
}

\author{
Lucy Rollins, Katie Coats, Marianne Elliott, and Gary Chastagner, Department of Plant Pathology, Washington State University Research \& \\ Extension Center, Puyallup 98371
}

\begin{abstract}
Rollins, L., Coats, K., Elliott, M., and Chastagner, G. 2016. Comparison of five detection and quantification methods for Phytophthora ramorum in stream and irrigation water. Plant Dis. 100:1202-1211.

Propagules of Phytophthora ramorum, the causal agent of sudden oak death (SOD) and ramorum blight, can be recovered from infested stream and nursery irrigation runoff using baiting and filtration methods. Five detection methods, including pear and rhododendron leaf baits, Bottle $\mathrm{O}$ ' Bait, filtration, and quantitative polymerase chain reaction (qPCR) performed on zoospores trapped on a filter were compared simultaneously in laboratory assays using lab or creek water spiked with known quantities of $P$. ramorum zoospores. The detection threshold for each method was determined and methods that could be used to quantify zoospore inoculum were identified. Filtration and qPCR

were the most sensitive at detecting low levels of zoospores, followed by wounded rhododendron leaves, rhododendron leaf disks, and pear baits. Filtration, qPCR, and leaf disks were able to quantify $P$. ramorum zoospores ranging from 2 to 451 direct-plate CFU/liter while wounded leaves and pear baits appeared to be better at detection rather than quantification. The ability to detect and quantify $P$. ramorum inoculum in water will assist scientists, regulatory agencies, and nursery personnel in assessing the risk of spreading $P$. ramorum in nurseries and landscape sites where untreated infested water is used for irrigation.
\end{abstract}

Nursery operations often collect and reuse irrigation runoff as a way to conserve water and to prevent the discharge of pollutants into the surrounding environment (U.S. EPA 2012). Moreover, surface water can be removed from rivers and streams and used for irrigation by nurseries and private landowners (Hong and Moorman 2005). Both sources have been shown to contain plant-pathogenic species of the genera Phytophthora and Pythium (Bush et al. 2003; MacDonald et al. 1994). Pythiaceous species are well adapted to survive in water, which is required for dispersal as well as for the formation of sporangia and motile zoospores, the primary propagules for the initiation of new infections (Judelson and Blanco 2005). Pythiaceous species have been shown to cause low levels of disease in hosts irrigated overhead with naturally infested water (Loyd et al. 2014).

Phytophthora ramorum, the causal agent of sudden oak death (SOD) and ramorum blight (Rizzo and Garbelotto 2003; Werres et al. 2001), has been found in streams associated with forest infestations (Davidson et al. 2005) and in surface water located within and adjacent to infested nurseries (Frankel 2008). Irrigating with water artificially and naturally infested with $P$. ramorum has resulted in low incidence of disease on hosts in simulated nursery settings (Tjosvold et al. 2008; Werres et al. 2007), and infection of native salal (Gaultheria shallon) has occurred when streamside plants came into contact with infested ditch water associated with a positive nursery during a flood event (Chastagner et al. 2013). In addition to the risk of infecting nursery stock by using $P$. ramorum-infested water for irrigation, there is concern that the pathogen may become established in forests and landscapes if streamside hosts are exposed to the pathogen in infested flood water (Jeffers et al. 2010).

Corresponding author: L. Rollins; E-mail: lucy.rollins@wsu.edu

PPNS Number 0703, Department of Plant Pathology, College of Agriculture, Human, and Natural Resources Sciences, Agricultural Research Center, Hatch Project Number WNP00388, Washington State University, Pullman 99164-6430

Accepted for publication 23 January 2016.

http://dx.doi.org/10.1094/PDIS-11-15-1380-RE

(C) 2016 The American Phytopathological Society
Reliable methods for the detection and quantification of Pythiaceous species are necessary for understanding and managing the risk of using untreated surface water or captured nursery runoff for irrigation. Baiting and filtration techniques are commonly used for the detection of Phytophthora spp. in irrigation and stream water. Baits used for the detection of $P$. ramorum include 'D'Anjou' pear (Davidson et al. 2005; Tjosvold et al. 2008) and Rhododendron spp. whole-leaf baits (Chastagner et al. 2010; Davidson et al. 2005; Sutton et al. 2009). Bottle O' Bait (BOB) is a relatively new in vitro method using both whole leaves and leaf disks (Oak et al. 2013). Filtration has been used for detection of Phytophthora spp. in nursery settings (Bush et al. 2003; Hong et al. 2002; MacDonald et al. 1994) and in forest streams (Reeser et al. 2011) and was used to quantify $P$. ramorum inoculum in rainwater (Davidson et al. 2008) and streams (Hwang et al. 2008).

The detection threshold concentration refers to the minimum number of propagules that baiting and filtration methods can detect (Hong and Moorman 2005). Understanding the detection threshold of the method used to find $P$. ramorum would help determine how many samples to take and what time of year is best for sample collection. Additionally, the ability to quantify propagule density in infested water may assist nursery owners, researchers, and government officials in disease management. If the concentration of $P$. ramorum is below the biological threshold required for infection of a known host, the risk of using infested water for irrigation may be reduced (Hong and Moorman 2005). Although filtration (Hwang et al. 2008) and pear baiting (Tjosvold et al. 2008) have been used to estimate $P$. ramorum propagule density in infested water, it is unknown if whole-leaf baits can be used to quantify propagule density.

Traditional detection methods are time consuming to perform and may lack the sensitivity to detect low densities of the propagules in stream and nursery water. Polymerase chain reaction (PCR) offers a fast, specific, and sensitive method for the detection of pathogenic fungi and oomycetes in plant tissue, soil, and water (Scibetta et al. 2012; Zhang et al. 2006). Propagules in water samples are collected through filtration, after which the filters are treated with chemicals to cause cell lysis and the release of nucleic acids. Commercial DNA extraction kits can be used for DNA purification (Hughes et al. 2006). Although quantitative real-time (q)PCR assays have been used for the detection and quantification of $P$. ramorum in plant tissue (Hayden et al. 2004, 2006) and soil (Colburn and Jeffers 2011; Sechler et al. 2006), a qPCR protocol has not been developed for 
the detection and quantification of $P$. ramorum in water (Sanzani et al. 2014).

Objectives for this research were to (i) develop a TaqMan qPCR assay to quantify $P$. ramorum zoospore density in spiked lab and creek water samples, (ii) simultaneously test multiple detection methods (pear baiting, whole-leaf baiting, BOB, filtration, and qPCR) using lab and creek water spiked with known quantities of $P$. ramorum zoospores to determine the detection threshold concentration for each method, and (iii) determine whether the detection methods could be used to quantify propagule density. Filtration and BOB methods were tested at various field locations, including sites where $P$. ramorum-positive detections have been made.

\section{Materials and Methods}

$P$. ramorum inoculum preparation. Cultures of an NA1 lineage isolate (03-74-N10A-A from Rhododendron $\times$ 'Unique', A2 mating type, collected from a production nursery in Oregon) were grown on one-third V8 agar $(66 \mathrm{ml}$ of clarified V8 concentrate $[100 \mathrm{ml}$ of V8 juice and $1.43 \mathrm{~g}$ of $\mathrm{CaCO}_{3}$ centrifuged $15 \mathrm{~min}$ at 5,000 rpm], $15 \mathrm{~g}$ of Difco Bacto agar, and $934 \mathrm{ml}$ of $\mathrm{H}_{2} \mathrm{O}$ ) for 4 weeks in the dark at $20^{\circ} \mathrm{C}$. Zoospore release was stimulated by flooding plates with $7 \mathrm{ml}$ of autoclaved deionized water, refrigerating the plates at $5^{\circ} \mathrm{C}$ for $2 \mathrm{~h}$, and then bringing the plates to room temperature for $1 \mathrm{~h}$. Released zoospores were harvested from plates by pouring the deionized water and its contents through eight layers of cheesecloth to remove mycelium and sporangia. Zoospore concentration (zoospores per milliliter) of the initial stock was determined using a hemocytometer. The zoospores were diluted to the concentrations used in experiments by carefully pipetting a specific amount of zoospore suspension into 1 liter of water. The zoospore suspension was gently stirred to help homogenize the suspension without causing the zoospores to encyst before pipetting. A negative control (0 zoospores) was made by flooding a noncolonized one-third V8 agar plate and pipetting $1 \mathrm{ml}$ into 1 liter of water. Zoospore densities were verified using a hemocytometer for concentrations greater than 1,000 zoospores $/ \mathrm{ml}$ and by direct plating of zoospores onto PARPH-V8 medium (one-third V8 agar amended with $10 \mathrm{mg}$ of Delvocid [50\% pimaricin], $250 \mathrm{mg}$ of sodium ampicillin, $10 \mathrm{mg}$ of Rifamycin-SV [sodium salt], $66.7 \mathrm{mg}$ of Terraclor [75\% pentachloronitrobenzene], and $50 \mathrm{mg}$ of Hymexazol) (Ferguson and Jeffers 1999) in 100-mm-diameter disposable petri plates. Plates were made just prior to baiting the water samples. CFU were counted using a dissecting microscope at 24,48 , and $72 \mathrm{~h}$ after inoculation. Three plates were made for each treatment and the average number of colonies per plate was determined for each trial. Zoospore concentration (zoospores per liter) was represented as direct-plate (DP) CFU per liter.

Experimental setup and water preparation. Detection methods tested were (i) baiting with a D'Anjou pear fruit, (ii) baiting with a single wounded rhododendron leaf, (iii) the BOB method, (iv) filtration, and (v) qPCR. Nine zoospore concentrations (treatments) were used: $0,25,50,100,250,500,1,000,10,000$, and 100,000 zoospores/liter of water to determine the detection threshold of each method. Lab and creek water were used in separate experiments. Deionized lab water was put into clean 1-liter Nalgene bottles (Thermo Fisher Scientific Inc., Waltham, MA) and autoclaved on a liquid cycle for $20 \mathrm{~min}$. Water was cooled to room temperature before adding zoospores and baits. There were three replicates for each zoospore concentration for each detection method tested. The experiment was repeated four times.

Water was collected in buckets from Clarks Creek (CC), a small spring-fed tributary to the Puyallup River, at the Washington State University (WSU) Puyallup Research and Extension Center in Puyallup, to evaluate how the detection methods performed under field conditions. Water was taken near the surface to avoid gathering any sediment in the sample in an area of the creek where the water flow rate was slow. The buckets of water were mixed together in an 18-gallon plastic storage box (Newell Rubbermaid Inc., Atlanta, GA) to homogenize the sample for each replication. There were three replicates of each zoospore concentration for each of the detection methods tested. The experiment was repeated twice. Lab and creek water quality measurements were taken with a portable meter (Hach Co.,
Loveland, $\mathrm{CO}$ ) and associated probes for water temperature, $\mathrm{pH}$, electrical conductivity (EC), dissolved oxygen (DO), and oxidationreduction potential (ORP).

Pear baiting. Green (unripe) D'Anjou pear fruit were acquired from a local store as needed and used within $24 \mathrm{~h}$ of purchase. Organic pear fruit were used when available. Pear fruit were washed with liquid (nonantibacterial) dish soap, rinsed, and allowed to air dry on paper towels. One pear was placed into a container (Glad 1.89liter "Deep Dish" style, 19 by $14 \mathrm{~cm}$ ) that was filled with 1 liter of lab (or creek) water that had been spiked with $P$. ramorum zoospores at the desired concentration. Plastic bird netting was used to hold the pear fruit in place so that only half of the pear would be submerged in the water at any given time. Pear fruit and water were held in an Animal and Plant Health Inspection Service (APHIS)-approved biocontainment unit at WSU Puyallup in $12 \mathrm{~h}$ of light $\left(7.00\right.$ to $\left.8.00 \mu \mathrm{mol} \mathrm{s}{ }^{-1} \mathrm{~m}^{-2}\right)$ and $12 \mathrm{~h}$ of darkness, at a temperature of $20^{\circ} \mathrm{C}$. Pear fruit were turned after $24 \mathrm{~h}$ to expose the entire surface to the pathogen. Pear fruit were removed from the water after a second $24-\mathrm{h}$ period and placed on paper towels for 2 to 4 days of incubation in the biocontainment unit under the same conditions listed above. Lesions caused by P. ramorum, described by Tjosvold et al. (2008) as being firm with diffuse edges and shaped in a rosette pattern, were visually identified and counted for each pear. Tissues from five discrete lesion margins were removed and plated into 100-mm petri dishes containing PARPH-V8 medium. If pear fruit had fewer than five lesions, tissues were removed from randomly chosen asymptomatic areas of the pear and plated onto PARPH-V8 so that there were always five tissue samples plated per fruit. Identification of $P$. ramorum was made based on morphological features of the colonies growing on PARPH-V8.

Whole-leaf baiting and BOB. Bait leaves were harvested from field-grown Rhododendron $\times$ 'Nova Zembla' at WSU Puyallup. Fully expanded and hardened leaves were selected. Leaves were surface sterilized with $0.5 \%$ hypochlorite solution for $30 \mathrm{~s}$, rinsed twice with distilled water, and blotted dry. A sterile 6-mm cork borer was used to make leaf disks. Whole leaves were wounded by folding the leaf into thirds and breaking across the midrib in two places. One wounded leaf was placed into a 1-liter Nalgene bottle containing 1 liter of lab (or creek) water spiked with $P$. ramorum zoospores at the desired concentration. Each concentration was replicated three times. Bottles were sealed, placed on their sides, and incubated in the biocontainment unit at $20^{\circ} \mathrm{C}$ for 3 days. The dimensions of the water surface when the bottle was placed on its side were 18 by $9 \mathrm{~cm}$. Leaves were removed from the bottle and placed between layers of moist paper towels in sealed plastic containers and incubated for up to 7 days to allow for lesion development. Leaves were removed from the moist chamber and blotted dry. Tissue from the leaf tip, petiole, and four discrete lesion margins was excised and transferred to PARPH-V8 medium. If leaves had fewer than four lesions, tissue was removed from asymptomatic areas that had been wounded so that there were always six tissue samples plated per leaf. Tissue material was incubated in the dark at $20^{\circ} \mathrm{C}$ for 7 days. Identification of $P$. ramorum was made based on morphological features of the colonies growing on PARPH-V8.

For the BOB method, a single wounded leaf and 10 leaf disks were placed into a plastic bottle containing 1 liter of lab (or creek) water spiked with $P$. ramorum zoospores at the desired concentration. There were three replications for each concentration. Bottles were incubated on their sides for 3 days in the biocontainment unit. The wounded leaves were processed as described above; the leaf disks were removed, blotted dry, and transferred to PARPH-V8 medium immediately after removal from the bottle. Identification of $P$. ramorum colonies growing on the PARPH-V8 media was made as described above.

Filtration. One liter of lab (or creek) water was placed in a plastic bottle and spiked with $P$. ramorum zoospores to obtain the desired concentration. There were three replications for each concentration. Bottle contents were vacuum-filtered using a Nalgene filter funnel and 1,000-ml flask (Thermo Fisher Scientific Inc.) through a Whatman polycarbonate membrane filter ( $3-\mu \mathrm{m}$ pore size, $47 \mathrm{~mm}$ in diameter; GE Healthcare Life Sciences, Pittsburgh) using a rotary-vane vacuum pump (Gast Manufacturing, Inc., Benton Harbor, MI) at approximately 4 to $7 \mathrm{kPa}$ for lab and creek water. Occasionally, a higher 
vacuum pressure was required to filter the creek samples. The vacuum pressure did not exceed $60 \mathrm{kPa}$ in those cases. Vacuum pressure was released as soon as all the water had passed through the filter to prevent damage to the zoospores. Filters were inverted onto thinly poured PARPH-V8 medium in disposable petri plates $(60 \mathrm{~mm}$ in diameter) and incubated at $20^{\circ} \mathrm{C}$ in the dark for 1 to 2 days. Filters were removed and emerging colonies of $P$. ramorum were counted for up to $72 \mathrm{~h}$. The surface of the agar was rinsed with deionized water to remove creek water debris before counting, as necessary. Creek water samples were filtered in 250-ml aliquots to prevent the filters from becoming clogged. For lab and creek water, the entire bottle contents were filtered for concentrations of $0,25,50$, and 100 zoospores/liter. A single $250-\mathrm{ml}$ aliquot was filtered per bottle for concentrations of 250,500 , and 1,000 zoospores/liter so as to obtain countable plates of approximately 30 to $50 \mathrm{CFU} /$ plate. The number of CFU per plate was multiplied by 4 to determine the number of CFU per liter. Single 25- and 5-ml aliquots were filtered per bottle for concentrations of 10,000 and 100,000 zoospores/liter, respectively, and the number of CFU per plate was multiplied by 40 and 200 , respectively, to obtain the number of CFU per liter.

qPCR assays for quantifying zoospores in water. One liter of lab (or creek) water was prepared to the desired zoospore concentration and filtered, as previously described. There were three replications for each concentration. Filters containing the trapped zoospores were placed into individual 2-ml screw-cap tubes and stored at $-80^{\circ} \mathrm{C}$ until DNA extraction. Preliminary testing identified cell lysis with sodium dodecyl sulfate (SDS) and proteinase K combined with DNA purification using silica-membrane columns from a NucleoSpin Plant kit (Macherey-Nagel Inc., Bethlehem, PA) as yielding significantly higher amounts of DNA product when compared with methods using cetyltrimethylammonium bromide (CTAB) combined with phenol chloroform, CTAB combined with silica-membrane columns, and SDS combined with phenol chloroform. Therefore, zoosporic DNA was extracted using a NucleoSpin Plant II kit following the protocol for genomic DNA from plants, with the following modification: cell lysis of zoospores was done following the method of Lefèvre et al. (2010), where filters were soaked overnight at $37^{\circ} \mathrm{C}$ in $12 \mu \mathrm{l}$ of proteinase $\mathrm{K}$ at $1 \mathrm{mg} \mathrm{ml}^{-1}$ and $500 \mu \mathrm{l}$ of a buffer containing $1 \%$ SDS, $1 \mathrm{mM}$ EDTA, and $10 \mathrm{mM}$ Tris-HCl. A clean pipette tip was used to squeeze the filter against the inside of the tube to remove as much of the buffer from the filter as possible, and the filter was removed and discarded. The entire lysate was bound to a single column (step 5 of the protocol) by multiple repetitions of the loading step in samples where multiple filters were used. A TaqMan qPCR assay, based on the APHIS protocol (USDA-APHIS PPQ 2013), was performed on a 7500 Sequence Detection System (Applied Biosystems, Waltham, MA) instrument. Each $25-\mu l$ qPCR included $2 \mu \mathrm{l}$ of DNA and $23 \mu \mathrm{l}$ of master mix: $12.5 \mu \mathrm{l}$ of $2 \times$ TaqMan Universal PCR Master Mix (no AmpErase UNG), $0.0125 \mu \mathrm{l}$ of Pram-114F (100 $\mu \mathrm{M}), 0.05 \mu \mathrm{l}$ of Pram-1527-190R (100 $\mu \mathrm{M}), 0.025 \mu \mathrm{l}$ of probe Pram-1527-134-T $(100 \mu \mathrm{M}), 0.025 \mu \mathrm{l}$ of internal positive control (IPC) Sketa F $(100 \mu \mathrm{M}), 0.025 \mu \mathrm{l}$ of IPC Sketa R $(100 \mu \mathrm{M}), 0.025 \mu \mathrm{l}$ of IPC Sketa probe $(100 \mu \mathrm{M}), 0.125 \mu \mathrm{l}$ of bovine serum albumin (BSA; $10 \mathrm{mg} / \mathrm{ml}), 2.375 \mu \mathrm{l}$ of trehalose $(50 \%), 1 \mu \mathrm{l}$ of salmon sperm DNA, and $6.8375 \mu \mathrm{l}$ of nuclease-free water. Cycling conditions were set at $50^{\circ} \mathrm{C}$ for $2 \mathrm{~min} ; 95^{\circ} \mathrm{C}$ for $10 \mathrm{~min}$; and 46 cycles of $95^{\circ} \mathrm{C}$ for $15 \mathrm{~s}, 58^{\circ} \mathrm{C}$ for $15 \mathrm{~s}$, and $60^{\circ} \mathrm{C}$ for $30 \mathrm{~s}$. Salmon sperm DNA (U.S. EPA 2010) was added to the reaction mix as an internal amplification control and was detected by Sketa primers and probe (Cao et al. 2012). The $P$. ramorum probe was labeled with a $5^{\prime}$ fluorescent FAM dye and nonfluorescent quencher and the Sketa probe was labeled with a $5^{\prime}$ fluorescent VIC dye and TAMRA quencher. BSA was added to reduce the effect of inhibitors on the yield of qPCR product. The optimal cutoff point (cycle threshold $\left[\mathrm{C}_{\mathrm{t}}\right]$ value) was determined using the Youden index in the context of the receiver operating characteristic (ROC) curve analysis, as described by Nutz et al. (2011). Samples with a $\mathrm{FAM} \mathrm{C}_{\mathrm{t}}$ value of 38 and above were considered to be negative for tests using lab and creek water. Standard curves were generated based on a dilution series of $P$. ramorum DNA from an NA1 lineage isolate (Pr1418886 from Camellia $\times$ 'Coral Delight', A2 mating type, collected from a nursery in Fairfax, Marin County, CA) containing $7 \times 10^{-1}$ to $7 \times 10^{-6} \mathrm{ng}$ of DNA. Each DNA sample including standards was assayed in triplicate. A water control was included as a negative control.

The estimated number of $P$. ramorum zoospores was determined by the equation $Y=X / 0.0001329 \mathrm{ng}$ of DNA, where $Y=$ the estimated number of zoospores, $X=$ the amount of recovered DNA (in nanograms), and $0.0001329=$ the DNA content of a single $P$. ramorum zoospore (in nanograms). The DNA content of one zoospore was determined by using the conversion factor of Dolezel et al. (2003), where $1 \mathrm{pg}$ of DNA represents $0.978 \times 10^{9} \mathrm{bp}$ and the $P$. ramorum genome size of $65 \mathrm{Mb}\left(0.065 \times 10^{9} \mathrm{bp}\right)$ estimated by Tyler et al. (2006). Assuming there are two copies of the genome per zoospore (Erwin and Ribeiro 1996), the DNA content of a single $P$. ramorum zoospore was determined by the equation $2 \times\left(0.065 \times 10^{9} \mathrm{bp} / 0.978 \times\right.$ $\left.10^{9} \mathrm{bp}\right)=0.1329 \mathrm{pg}$ of DNA $(0.0001329 \mathrm{ng}$ of DNA $)$.

Field sampling. Detection methods were tested at two Washington wholesale nurseries, henceforth referred to as Nursery 1 (N1) and Nursery 2 (N2), located in King and Thurston counties; and at the Dungeness River (DR) and Gierin Creek (GC), both located in Clallam County, WA. Filtration and the BOB method were used to test for the presence of Phytophthora spp. in a retention pond and swale that connect the pond to a drainage ditch bordering the property at N1. $P$. ramorum had not been previously recovered from either the pond or swale. Eight 1-liter samples were collected from various locations around the perimeter of the pond and swale in March 2013 using a 1-liter Nalgene bottle attached to a pole approximately $3.048 \mathrm{~m}$ from the water edge and at roughly $0.3048 \mathrm{~m}$ below the water surface. Filtration and $\mathrm{BOB}$ methods were conducted as described previously; however, water samples were filtered in $100-\mathrm{ml}$ aliquots to prevent the filters from becoming clogged. Colonies were identified using morphological characteristics to either Pythium or Phytophthora genus.

Filtration, $\mathrm{BOB}$, and $\mathrm{qPCR}$ were used to detect the presence of $P$. ramorum at DR, GC, and the drainage pond at N2 in July 2013. $P$. ramorum had previously been recovered from the river and drainage pond. Three 1-liter samples were collected at single locations at DR and GC while 1-liter samples were collected from four locations around the drainage pond perimeter. Samples were collected as described for N1. At DR and GC, 1-liter aliquots were pooled, mixed, and poured into 1-liter bottles to homogenize the sample. Temperature, $\mathrm{pH}, \mathrm{EC}, \mathrm{DO}$, and ORP were recorded at the time of collection.

Filtration, $\mathrm{BOB}$, and $\mathrm{qPCR}$ methods were conducted as described above; however, water samples were filtered in 100-ml aliquots for filtration and in 250-ml aliquots for qPCR to prevent the filters from becoming clogged. DNA from multiple filters was combined onto a single column by multiple repetitions of the loading step. A positive control consisting of an additional 1 liter water sample that was "spiked" with a known quantity of $P$. ramorum zoospores was included for qPCR. Phytophthora and Pythium isolates from DR, GC, and N2 were identified morphologically. DNA sequencing of the internal transcribed spacer (ITS) region of the nuclear ribosomal DNA, using the ITS4 and ITS6 primers (Cooke et al. 2000; White et al. 1990), was performed for identification of select colonies from the drainage pond at N2.

Statistical analysis. The relationship between DP CFU per liter and the number of lesions on pear fruit, leaves, infected leaf disks, filtration CFU, and DNA quantity was assessed with simple linear regression (PROC REG, SAS 9.2; SAS Institute Inc., Cary, NC) using mean values of three replicates of each treatment (zoospore concentration) for each trial. Data sets were transformed using a logarithmic (base e) transformation, with a "1" added to each mean value to retain the ability to analyze means with values below 1 .

\section{Results}

Water quality measurements. Lab water had lower $\mathrm{pH}, \mathrm{EC}$, and DO and higher temperature and ORP than water from CC (Table 1). Water $\mathrm{pH}, \mathrm{EC}, \mathrm{DO}$, and ORP readings were similar for N1, N2, and CC. $\mathrm{N} 2$ had a higher water temperature than N1, CC, DR, and GC. DR, GC, and lab water had lower $\mathrm{pH}$ and EC readings than N1, N2, and CC.

Detection threshold. Filtration consistently detected $P$. ramorum zoospores in 83 to $100 \%$ of the replications at all concentration levels 
for both lab and creek water trials (Table 2). Similarly, qPCR was able to detect zoospore DNA in 92 to $100 \%$ of all replications, with one exception, where the method failed to detect DNA in three of the six creek water replications at the lowest zoospore concentration. Although BOB and leaf-only methods were able to detect zoospores at low concentration levels, the percentage of positive replications was much lower than those for filtration and qPCR. BOB leaf disks and leaves were found to have positive detections in 83 and $100 \%$, respectively, of the creek water trial replications at concentrations between 171 and 173 DP CFU/liter and in 66 and 75\%, respectively, of the lab water replications at concentrations between 72 and 206 DP CFU/liter (Table 2). In comparison, the percentage of positive replications for the leaf-only method was 100 and $67 \%$ for creek and lab trials, respectively, at similar concentration ranges. Pear baiting had the highest detection threshold, in which 83 to $100 \%$ of all replicates were positive at concentrations between 1,067 and 3,033 DP CFU/liter for lab trials and between 381 and $396 \mathrm{DP}$ CFU/liter for creek trials (Table 2).

$P$. ramorum was recovered once from asymptomatic pear tissue in a trial using creek water. There was not a noticeable difference in the number of infections between organic and nonorganic pear. Infected BOB leaf disks appeared to be asymptomatic in both types of water. Symptomatic leaf petioles and leaf tips were infected with
$P$. ramorum between 43 and $65 \%$ of the time. One symptomatic piece of leaf tissue was negative for $P$. ramorum and three asymptomatic pieces of leaf tissue were positive in lab water trials. Leaf lesions caused by $P$. ramorum could not be visually distinguished from those caused by other Phytophthora and Pythium spp. in the trials using creek water.

Zoospore quantification. Filtration CFU, recovered DNA, and positive leaf disk baits showed significant linear relationships with DP CFU per liter in both lab and creek trials for concentrations in the range of 25 to 1,000 zoospores/liter (2 to $451 \mathrm{DP}$ CFU/liter; Table 3). Two exceptions occurred where the linear relationships between DP CFU per liter and recovered DNA (lab trial 3) and positive BOB leaf disks (lab trial 4$)$ were not significant $\left(P=0.1614, R^{2}=\right.$ 0.4239 and $P=0.1175, R^{2}=0.4975$, respectively). The relationship between $P$. ramorum-positive leaf baits and DP CFU per liter was significant in three of the BOB lab and creek trials and in two of the trials using single rhododendron leaf baits. $P$. ramorum pear lesions had a significant linear relationship with DP CFU per liter in one lab trial and one creek trial. At concentrations $>1,000$ zoospores/liter, individual pear and leaf lesions could not be accurately counted. Filtration and qPCR methods, on the other hand, were able to quantify zoospores at higher concentrations. Filtration colony counts were found to have a significant linear relationship with DP CFU per liter

Table 1. Water quality measurements for lab and field water used for detection methods testing and from field samples ${ }^{\mathrm{a}}$

\begin{tabular}{|c|c|c|c|c|c|c|}
\hline Source $^{\mathbf{b}}$ & Date & pH & $\mathrm{EC}(\mathrm{mS} / \mathrm{cm})$ & DO (mg/liter) & ORP $(\mathbf{m V})$ & Temperature $\left({ }^{\circ} \mathbf{C}\right)^{\mathrm{c}}$ \\
\hline Lab & 3 September 13 & 6.36 & 0.058 & 7.43 & 347.2 & 23.0 \\
\hline Lab & 8 June 14 & 5.52 & 0.078 & 8.50 & 339.7 & 21.4 \\
\hline Clarks Creek Trial 1 & 6 January 14 & 7.43 & 0.226 & 8.92 & 215.9 & 12.6 \\
\hline Clarks Creek Trial 2 & 21 January 14 & 7.59 & 0.225 & 9.59 & 264.4 & 12.7 \\
\hline Nursery 1 pond & 3 March 13 & 7.79 & 0.226 & ND & ND & 12.5 \\
\hline Nursery 2 pond & 30 July 13 & 7.55 & 0.262 & 9.16 & 255.1 & 19.1 \\
\hline Dungeness River & 11 July 13 & 6.43 & 0.089 & 10.05 & ND & 12.3 \\
\hline Gierin Creek & 11 July 13 & 6.51 & 0.131 & 8.98 & ND & 14.0 \\
\hline
\end{tabular}

a $\mathrm{EC}=$ electrical conductivity, $\mathrm{DO}=$ dissolved oxygen, $\mathrm{ORP}=$ oxidation-reduction potential, and $\mathrm{ND}=$ no data; water quality measurements were not taken.

b Simultaneous detection methods testing was performed using cooled, autoclaved deionized lab water and water taken from Clarks Creek located at Washington State University Puyallup. Field sampling was conducted at two nursery sites (Nursery 1 and Nursery 2 ponds), the Dungeness River, and Gierin Creek. Water quality data shown are the average of three measurements taken per source.

c Temperature of lab and creek water immediately prior to the addition of zoospores and baits, and temperature of water at field sites immediately prior to the addition of baits.

Table 2. Percentage of positive replications for each detection method at all zoospore concentrations tested

\begin{tabular}{|c|c|c|c|c|c|c|c|}
\hline \multirow[b]{2}{*}{ Concentration $^{b}$} & \multirow[b]{2}{*}{ DP CFU ${ }^{\mathrm{c}}$} & \multicolumn{6}{|c|}{ Positive $(\%)^{\mathbf{a}}$} \\
\hline & & Filtration & qPCR & BOB disks & BOB leaf & Leaf only & $\overline{\text { Pear }}$ \\
\hline \multicolumn{8}{|l|}{$\overline{\text { Lab trials }}$} \\
\hline 25 & $2-13$ & 100 & 92 & 25 & 33 & 50 & 8 \\
\hline 50 & $6-19$ & 100 & 92 & 25 & 42 & 50 & 8 \\
\hline 100 & $11-58$ & 83 & 100 & 33 & 25 & 67 & 33 \\
\hline 250 & $28-114$ & 100 & 100 & 41 & 50 & 58 & 33 \\
\hline 500 & $72-206$ & 100 & 100 & 66 & 75 & 67 & 50 \\
\hline 1,000 & $127-451$ & 100 & 100 & 75 & 75 & 67 & 58 \\
\hline 10,000 & $1,067-3,033$ & 100 & 100 & 100 & 100 & 58 & 100 \\
\hline 100,000 & $18,133-76,000$ & 100 & 100 & 100 & 100 & 100 & 100 \\
\hline \multicolumn{8}{|l|}{ Creek trials } \\
\hline 25 & $7-8$ & 100 & 50 & 17 & 33 & 67 & 0 \\
\hline 50 & $13-19$ & 100 & 100 & 17 & 0 & 33 & 17 \\
\hline 100 & $27-35$ & 100 & 100 & 67 & 83 & 67 & 17 \\
\hline 250 & $71-82$ & 100 & 100 & 83 & 67 & 100 & 0 \\
\hline 500 & $171-173$ & 100 & 100 & 83 & 100 & 100 & 33 \\
\hline 1,000 & $381-396$ & 100 & 100 & 100 & 100 & 100 & 83 \\
\hline 10,000 & $1,440-1,882$ & 100 & 100 & 100 & 100 & 100 & 83 \\
\hline 100,000 & $21,966-46,367$ & 100 & 100 & 100 & 100 & 100 & 100 \\
\hline
\end{tabular}

a Percentage of replications that had positive detections of $P$. ramorum, where $n=12$ for lab water trials and $n=6$ for creek water trials. qPCR $=$ quantitative polymerase chain reaction and $\mathrm{BOB}=$ Bottle $\mathrm{O}^{\prime}$ Bait.

b Concentration of Phytophthora ramorum zoospores/liter for each treatment.

${ }^{c}$ Range of the mean number of direct-plate (DP) CFU per liter from four trials using lab water and two trials using creek water, where $n=3$ for each trial. Plates were made just prior to adding baits to the water. 
in lab $\left(P<0.0001, R^{2}=0.9557\right)$ and $\operatorname{creek}\left(P<0.0001, R^{2}=0.9657\right)$ trials when concentrations $>1,000$ zoospores/liter were included in the linear regression analysis for combined trials (data not shown). Similarly, a significant linear regression was found between recovered DNA and DP CFU per liter in lab $\left(P<0.0001, R^{2}=0.6561\right)$ and creek $\left(P<0.0001, R^{2}=0.6993\right)$ trials when higher zoospore concentrations were taken into consideration (data not shown).

An average regression line of four lab and two creek water trials was used for estimation of zoospore density as measured by DP CFU per liter for concentrations between 25 and 1,000 zoospores/liter (Fig. 1 and 2). Significant linear relationships between DP CFU and filtration CFU (Fig. 1A) and recovered DNA (Fig. 1B) were shown for both lab and creek trials. BOB leaf disk trials also had significant linear relationships between positive disks and colony counts; however, there was a higher degree of variability when compared with filtration and qPCR methods (Fig. 1C). Whole leaves and pear baits had significant linear relationships with DP CFU per liter for creek trials only and showed more variability between trials than filtration CFU, recovered DNA, and BOB leaf disks (Fig. 2).

The number of DP and filtration colonies ranged from 8 to $30 \%$ (average $20 \%$ ) and 4 to $12 \%$ (average $8 \%$ ), respectively, of the $P$. ramorum zoospores counted by hemocytometer in the creek trials (Table 4). DP and filtration colonies ranged from 2 to $40 \%$ (average 22\%) and 6 and

Table 3. Summary statistics for regression analysis between DP CFU per liter of lab or creek water and the number of filtration CFU, zoospore DNA, positive leaf disks, and pear or leaf lesions caused by Phytophthora ramorum for concentrations ranging from 25 to 1,000 zoospores/liter ${ }^{\mathrm{a}}$

\begin{tabular}{|c|c|c|c|c|}
\hline Detection method & Trial & $\mathbf{D F}^{\mathbf{b}}$ & $P$ value & $R^{2}$ \\
\hline \multirow[t]{6}{*}{ Filtration } & Lab 1 & 4 & 0.0001 & 0.9811 \\
\hline & Lab 2 & 4 & 0.0248 & 0.7541 \\
\hline & Lab 3 & 4 & 0.0036 & 0.9042 \\
\hline & Lab 4 & 4 & 0.0018 & 0.9322 \\
\hline & Creek 1 & 4 & $<0.0001$ & 0.9948 \\
\hline & Creek 2 & 4 & 0.0004 & 0.9675 \\
\hline \multirow[t]{6}{*}{$\mathrm{qPCR}^{\mathrm{c}}$} & Lab 1 & 4 & 0.0019 & 0.9292 \\
\hline & Lab 2 & 4 & 0.0166 & 0.7974 \\
\hline & Lab 3 & 4 & 0.1614 & 0.4239 \\
\hline & Lab 4 & 4 & 0.0121 & 0.8259 \\
\hline & Creek 1 & 4 & 0.0337 & 0.7160 \\
\hline & Creek 2 & 4 & 0.0327 & 0.7200 \\
\hline \multirow[t]{6}{*}{ BOB leaf disks } & Lab 1 & 4 & 0.0077 & 0.8604 \\
\hline & Lab 2 & 4 & 0.0016 & 0.9362 \\
\hline & Lab 3 & 4 & 0.0272 & 0.7433 \\
\hline & Lab 4 & 4 & 0.1175 & 0.4975 \\
\hline & Creek 1 & 4 & 0.0238 & 0.7589 \\
\hline & Creek 2 & 4 & 0.0003 & 0.9723 \\
\hline \multirow[t]{6}{*}{ BOB leaf } & Lab 1 & ND & $\mathrm{ND}$ & ND \\
\hline & Lab 2 & 4 & 0.0073 & 0.8641 \\
\hline & Lab 3 & 4 & 0.0396 & 0.6937 \\
\hline & Lab 4 & 4 & 0.0806 & 0.5750 \\
\hline & Creek 1 & 4 & 0.0664 & 0.6106 \\
\hline & Creek 2 & 4 & 0.0075 & 0.8621 \\
\hline \multirow[t]{6}{*}{ Leaf only } & Lab 1 & 4 & 0.9330 & 0.0020 \\
\hline & Lab 2 & 4 & 0.0543 & 0.6452 \\
\hline & Lab 3 & 4 & 0.0012 & 0.9439 \\
\hline & Lab 4 & 4 & 0.0693 & 0.6031 \\
\hline & Creek 1 & 4 & 0.0898 & 0.5538 \\
\hline & Creek 2 & 4 & 0.0078 & 0.8596 \\
\hline \multirow[t]{6}{*}{ Pear } & Lab 1 & 4 & 0.6652 & 0.0516 \\
\hline & Lab 2 & 4 & 0.0216 & 0.7701 \\
\hline & Lab 3 & 4 & 0.0593 & 0.6305 \\
\hline & Lab 4 & 4 & 0.0967 & 0.5387 \\
\hline & Creek 1 & 4 & 0.0277 & 0.7413 \\
\hline & Creek 2 & 4 & 0.0809 & 0.5741 \\
\hline
\end{tabular}

$33 \%$ (average 15\%), respectively, of the zoospore hemocytometer counts for lab water trials (data not shown). $C_{t}$ values were similar between creek trials for individual concentrations, except at 10,000 zoospores/liter. The amount of DNA in trial 2 was lower than in trial 1. Estimated zoospore counts based on recovered DNA ranged from 1 to $22 \%$ (average $9 \%$ ) of zoospore hemocytometer counts in creek trials (Table 4 ) and 1 to $66 \%$ (average $35 \%$ ) for lab trials (data not shown).

Field sampling. $P$. ramorum was not found at DR, GC, or the N2 drainage pond using the detection methods. More colonies were identified as Phytophthora spp. from lesions that developed on nonwounded leaves and more colonies were identified as Pythium spp. when using filtration (Table 5). More colonies were identified as Pythium spp. when collected from leaf disks at N1 whereas results were mixed at the other sites. $P$. ramorum was not detected in the "unspiked" DR and GC samples using qPCR methods but it was detected in the spiked samples. Samples from GC and N2 required an additional dilution of 1:10 or 1:100 before the amplification control (Sketa) could be detected. Although $P$. ramorum DNA was detected in diluted unspiked samples from $N 2$, the $C_{t}$ values were above the $C_{t}$ cutoff value of 38 as determined by ROC analysis (Nutz et al. 2011).

\section{Discussion}

This study provided a comparison of five $P$. ramorum detection methods run simultaneously under controlled laboratory settings using zoospore suspensions made with either autoclaved deionized lab or noninfested creek water spiked with known quantities of $P$. ramorum zoospores. All bait types were effective at detecting a range of zoospores in water. The data suggest that leaf material was more sensitive at detecting low concentrations of $P$. ramorum zoospores than pear fruit; all baits had a wider detection threshold range than filtration and qPCR methods. Filtration and qPCR methods could be used for detection as well as quantification of zoospores in both types of water. Counting the number of $P$. ramorum-positive leaf disks could be used to quantify zoospore density in lab and creek trials. The relationship between the number of positive pear and leaf lesions and zoospore concentration was significant in some trials but, in general, the data suggest that wounded leaf and whole-pear baits were better at detecting $P$. ramorum than quantifying inoculum density.

In situ baiting using detached rhododendron leaves in bait bags has been used since 2006 to detect $P$. ramorum as part of the National Phytophthora ramorum Early Detection Survey of Forests (Chastagner et al. 2010). The standard national survey protocol (USDA APHIS PPQ 2014) was expanded to include the use of BOB in 2013 (Oak 2014). In a comparison of methods conducted in 2011 and 2012 (Oak 2014), the BOB method was found to be more effective at detecting $P$. ramorum when used in the spring, during which time the overall recovery rate for $P$. ramorum is generally higher, while bait bags were more effective in the fall, when recovery rates of $P$. ramorum are generally lower. Data suggest that wounded rhododendron leaves were better than leaf disks at detecting lower concentrations of zoospores ( $<20 \mathrm{DP} \mathrm{CFU} / \mathrm{liter}$ ); however, wounded leaf and disk baits were similar in their ability to detect $P$. ramorum at concentrations $>20$ DP CFU/liter (Table 2).

A positive relation between the number of infected leaf disks and $P$. ramorum inoculum concentration in run-off water has been shown in prior research (Tjosvold et al. 2010). Leaf disks were able to quantify zoospore density up to $451 \mathrm{DP}$ CFU/liter (1,000 zoospores/liter) in trials using creek water, where the $P$. ramorum disk infection rate within the replications was found to be $43.3 \%$ (Table 4). Creek trial data show leaf disks to be nearly $100 \%$ colonized at concentrations $>1,440$ DP CFU/liter (>10,000 zoospores/liter). Further research should be conducted to determine the quantification cut-off value, when the rate of infection reaches between 80 to $100 \%$ of the disks.

Pear bait had the highest detection threshold of all the methods tested and might not be able to detect low concentrations of zoospores in streams or nursery effluents. Unlike leaf disks or pieces of symptomatic leaf tissue, where several isolates grew from each piece of tissue that was plated onto PARPH-V8 medium, each piece of pear tissue generally resulted in a single distinct colony, which facilitated visual identification of $P$. ramorum isolates in creek water. Tjosvold et al. (2008) used three D'Anjou pear fruit to bait 8-liter 
aliquots of stream water and found a concentration of approximately two infective $P$. ramorum propagules per liter of stream water. Using more than a single pear in a larger volume of water may increase the reliability of this method at detecting $P$. ramorum zoospores in water.

Filtration colony counts were strongly related to zoospore density in both lab and creek water spiked with $P$. ramorum zoospores. Data show filtration colony counts were generally less than direct plant colony counts in lab and creek trials. Differences between methods may be caused by the loss of zoospores through the filter pores (Hong et al. 2002) or damage to the zoospores caused by the pump vacuum pressure, or may have occurred because of the difficulty of counting individual colonies that are in close proximity to each other on the filter, especially at higher zoospore concentrations.

Average DP colony counts were 22 and $20 \%$ of the zoospores counted by hemocytometer for lab and creek water trials, respectively. Kong et al. (2012a) found a germination rate of less than
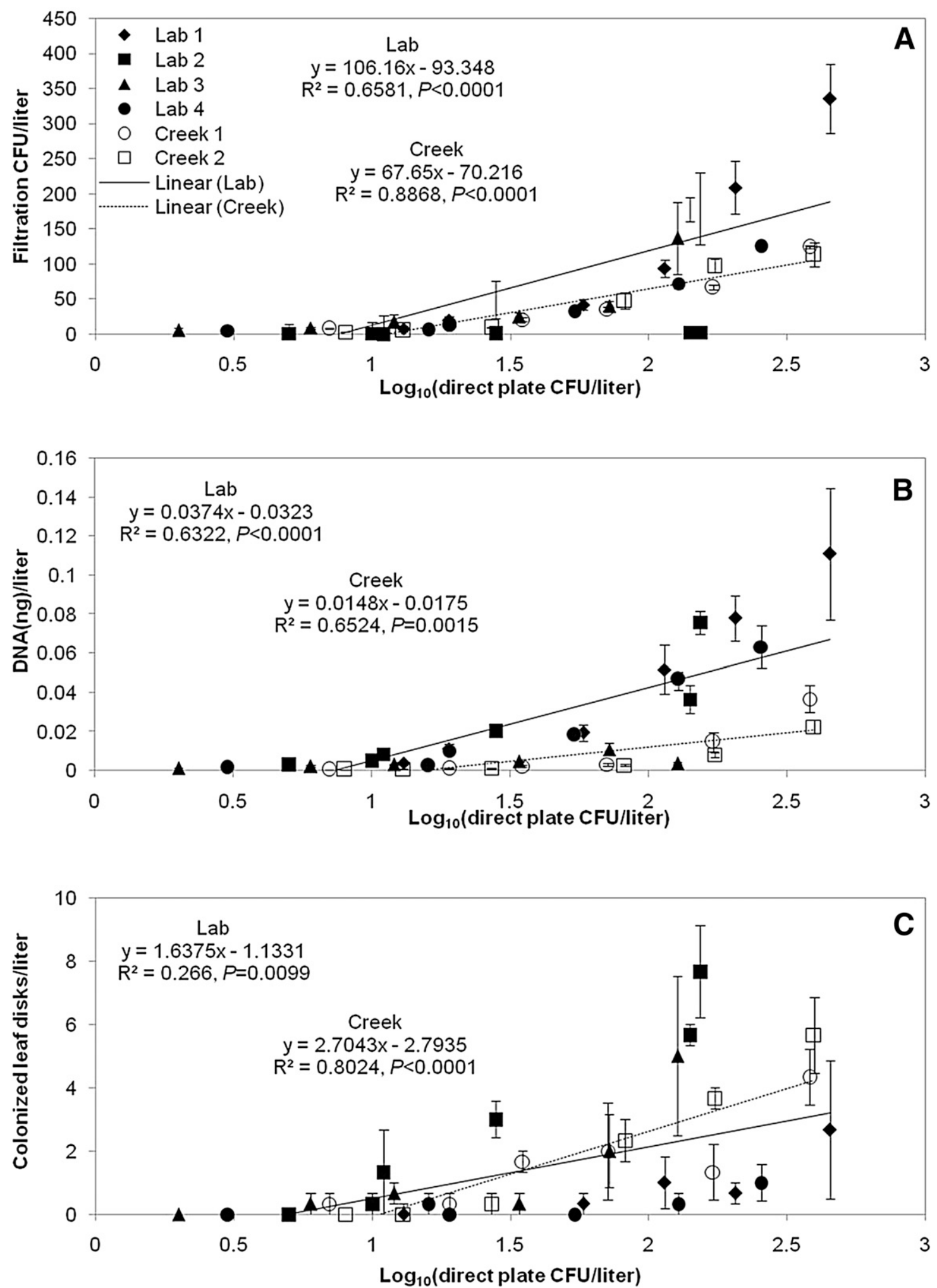

Fig. 1. Relationship between direct-plate CFU and A, filtration CFU; B, recovered DNA; and C, positive leaf disks for the Bottle O' Bait method in four trials using lab water and two trials using creek water. Concentrations range between 25 and 1,000 zoospores/liter. Error bars represent standard error, $n=3$. 
$20 \%$ when $P$. ramorum zoospores were plated directly onto PARP-V8 medium while Hao et al. (2012) reported $13 \%$ of motile $P$. nicotianae zoospores germinated when placed in PARP-V8 broth. Average filtration colony counts were 15 and $8 \%$ of the zoospores counted by hemocytometer for lab and creek trials, respectively. Germination rates for $P$. ramorum zoospores captured on a filter have been reported to be between 10 and $15 \%$ for motile zoospores (J. Hwang, personal communication) while the filtration recovery rate of $P$. cryptogea zoospores was found to be in the range of 10 to $20 \%$ (MacDonald et al. 1994). P. ramorum was detected using filtration at densities of 2,36 , and $130 \mathrm{CFU} / \mathrm{liter}$ in California streams (Hwang et al. 2008). Assuming that the filtration process captured the low end of the recovery rate (MacDonald et al. 1994) or $10 \%$ of $P$. ramorum zoospores, actual zoospore densities would be closer to 20,360, and 1,300 zoospores/liter.

Humic and tannic acids are phenolic compounds found in natural water that can reduce the sensitivity of detection of $P$. ramorum in rivers and streams by binding to DNA, effectively reducing the amount of available DNA template that can be amplified during the qPCR (Opel et al. 2010). Tannic acid also interacts with the
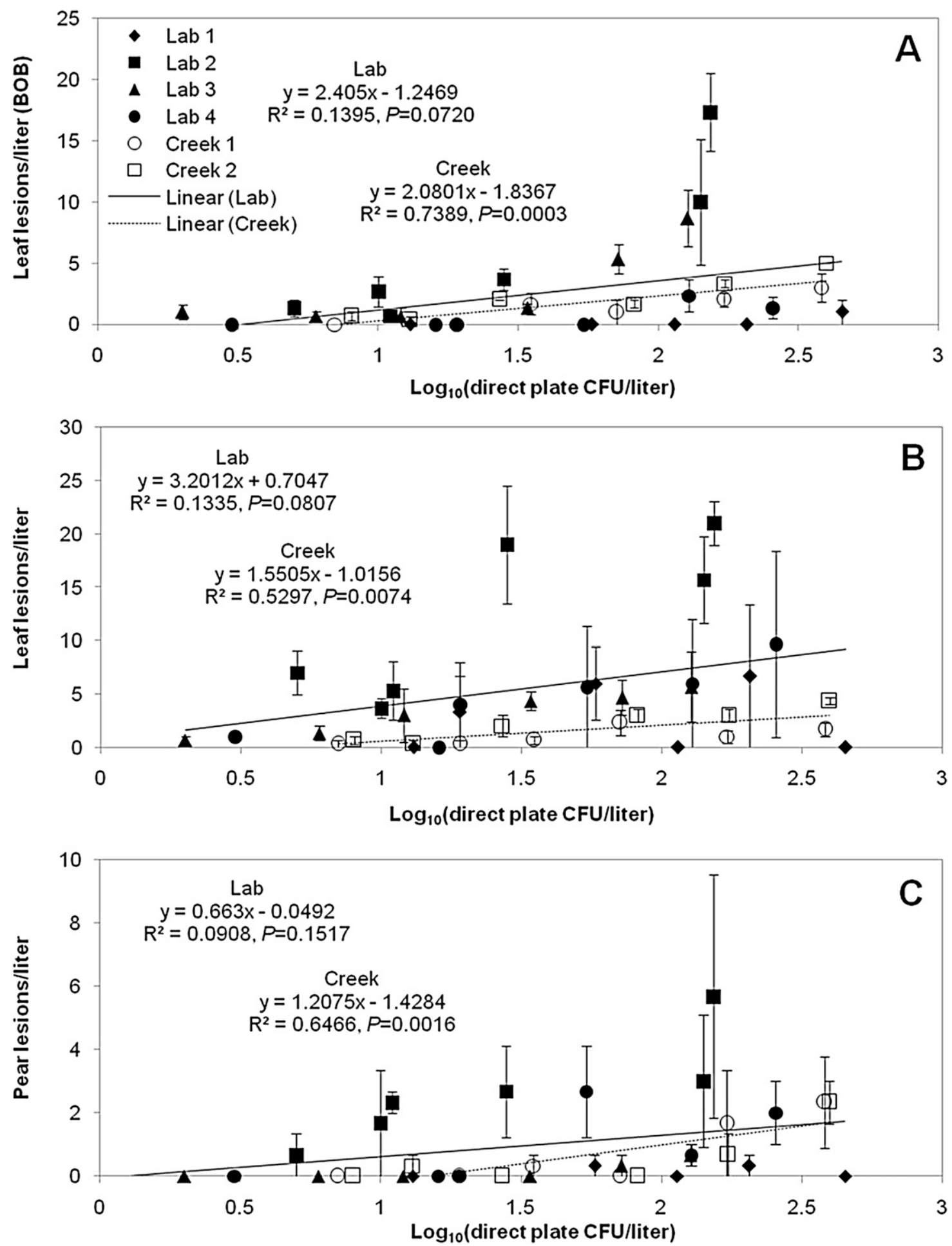

Fig. 2. Relationship between direct-plate CFU and A, positive leaf lesions (Bottle O' Bait); B, positive leaf lesions for single leaves; and C, positive pear lesions in four trials using lab water and two trials using creek water. Concentrations range between 25 and 1,000 zoospores/liter. Error bars represent standard error, $n=3$. 
Taq polymerase, making it inoperable during qPCR (Opel et al. 2010). BSA, which binds to endogenous phenolic compounds (Kreader 1996), was added to the final qPCR mix to improve detection of $P$. ramorum. Salmon testes DNA (Sketa) was added as an amplification control to evaluate the impact of inhibition in the final reaction mixture for all qPCR samples. A sample was considered inhibited if the Sketa $C_{t}$ value was increased above 3.0 cycles from an uninhibited reference sample analyzed on the same plate (U.S. EPA 2010). Trials using lab and creek water had increased Sketa $C_{t}$ values within 1 and 3 cycles, respectively, of the reference samples. Two creek water samples, one at a concentration of 10,000 zoospores/liter and one at 100,000 zoospores/liter, had Sketa $C_{t}$ values above 3 cycles of the reference sample; therefore, data from these samples were excluded from trial $C_{t}$ and recovered DNA means. Sketa $C_{t}$ values were within 3 cycles of the reference samples for DR but samples collected from GC and N2 required an additional dilution of 1:10 or 1:100 before Sketa DNA could be detected.

There were strong linear relationships between recovered DNA and DP CFU per liter in all trials, with the exception of lab trial 3 (Table 3; Fig. 1B). Low amounts of recovered DNA at the concentration range between 127 and 451 DP CFU/liter may have occurred because of a pipetting error while spiking the deionized water during the initial setup. In preliminary work, a significant linear relationship was found between the number of $P$. ramorum zoospores visually counted on a microscope slide and DNA quantified using qPCR for zoospores in solution $\left(R^{2}=0.7308, P=0.0095\right)$ and for zoospores trapped on a filter $\left(R^{2}=0.8046, P=0.014\right)$.

The estimated number of zoospores based on recovered DNA was much lower than the number of zoospores counted with a hemocytometer for lab (data not shown) and creek (Table 4) trials. Zoospores may have passed through the filter pores during filtration (Hong et al. 2002); however, the filtrate was not tested to see if it contained zoospores. Additionally, trapped creek water particulates may have interfered with the removal of the buffer solution from the filter. Clement et al. (2013) found the estimated number of $P$. infestans zoospores based on qPCR to be slightly lower than the number of zoospores counted using a microscope, while a significant linear relationship between the two variables was found $\left(R^{2}=0.78, P<0.05\right)$.

A potential drawback of using qPCR for $P$. ramorum detection is that qPCR amplifies all detectable DNA regardless of whether it comes from viable or nonviable zoospores, making it possible to have a false-positive result or an overestimation of propagule density (Raith et al. 2014). False-positive results may be avoided by the inclusion of culture-based methods that identify viable zoospores along with quantification using qPCR.

Table 4. Comparison of Phytophthora ramorum zoospore quantification methods for trials using creek water

\begin{tabular}{|c|c|c|c|c|c|c|c|}
\hline Concentration $^{\mathbf{a}}$ & Hemocytometer ${ }^{b}$ & DP CFU ${ }^{c}$ & Filtration CFU ${ }^{d}$ & $\mathbf{B O B}^{\mathbf{e}}$ & $\mathbf{C}_{\mathbf{t}}^{\mathbf{f}}$ & DNA (ng) ${ }^{g}$ & Estimated zoospores \\
\hline \multicolumn{8}{|l|}{ Trial 1} \\
\hline 0 & 0 & 0 & 0 & 0 & Undetectable & Undetectable & 0 \\
\hline 25 & ND & 7 & 8 & 3.3 & 37.09 & 0.0006 & 5 \\
\hline 50 & ND & 19 & 14 & 3.3 & 36.37 & 0.0010 & 8 \\
\hline 100 & ND & 35 & 21 & 16.7 & 35.06 & 0.0022 & 17 \\
\hline 250 & ND & 71 & 36 & 20.0 & 34.59 & 0.0032 & 24 \\
\hline 500 & ND & 171 & 67 & 13.3 & 32.16 & 0.0147 & 111 \\
\hline 1,000 & 1,250 & 381 & 124 & 43.3 & 29.61 & 0.0366 & 275 \\
\hline 10,000 & 9,875 & 1,880 & 1,147 & 76.7 & 27.60 & 0.1029 & 774 \\
\hline 100,000 & 97,375 & 21,966 & 8,333 & 96.7 & 23.56 & 1.2427 & 9,351 \\
\hline \multicolumn{8}{|l|}{ Trial 2} \\
\hline 0 & 0 & 0 & 0 & 0 & Undetectable & Undetectable & 0 \\
\hline 25 & ND & 8 & 3 & 0 & 36.77 & 0.0004 & 3 \\
\hline 50 & ND & 13 & 5 & 0 & 35.63 & 0.0008 & 6 \\
\hline 100 & ND & 27 & 9 & 3.3 & 34.84 & 0.0012 & 10 \\
\hline 250 & ND & 82 & 48 & 23.3 & 33.44 & 0.0028 & 22 \\
\hline 500 & ND & 173 & 97 & 36.7 & 31.76 & 0.0081 & 61 \\
\hline 1,000 & 2,250 & 396 & 113 & 56.7 & 30.01 & 0.0225 & 169 \\
\hline 10,000 & 18,250 & 1,440 & 1,773 & 100 & 30.23 & 0.0205 & 154 \\
\hline 100,000 & 185,750 & 46,367 & 7,600 & 100 & 22.50 & 1.4710 & 11,068 \\
\hline
\end{tabular}

${ }^{\text {a }}$ Concentration of $P$. ramorum zoospores/liter for each treatment.

${ }^{\mathrm{b}}$ Mean number of $P$. ramorum zoospores/liter from three hemocytometer counts. ND = no data; hemocytometer counts were not taken for zoospore densities below 1,000 zoospores/liter.

c Mean number of direct-plate (DP) CFU per liter that formed on PARPH-V8 medium, $n=3$. Plates were made just prior to adding baits to the water.

d Mean number of filtration CFU per liter that formed on PARPH-V8 medium, $n=3$.

e Bottle O' Bait (BOB) leaf disks; percentage of P. ramorum-infected leaf disks (out of 10), $n=3$.

${ }^{f}$ Threshold cycle $\left(C_{t}\right)$ number when fluorescence intensity of the sample exceeded background fluorescence intensity. The $C_{t}$ value is the mean of three sample replicates for concentrations 0 to 1,000 zoospores/liter and two replicates for 10,000 and 100,000 zoospores/liter.

g $P$. ramorum DNA mean of three sample replicates (0 to 1,000 zoospores/liter) and two replicates (10,000 and 100,000 zoospores/liter).

${ }^{\text {h }}$ Estimated number of $P$. ramorum zoospores determined by the equation $Y=X / 0.0001329 \mathrm{ng}$, in which $Y=$ the number of zoospores, $X=$ recovered DNA (ng) and $0.0001329 \mathrm{ng}=$ the DNA content of one zoospore.

Table 5. Number of colonies identified as belonging to either Phytophthora or Pythium spp. from 1-liter field samples using Bottle O’ Bait (BOB) and filtration recovery methods

\begin{tabular}{|c|c|c|c|c|c|c|}
\hline \multirow[b]{2}{*}{ Source } & \multicolumn{2}{|c|}{ BOB disks } & \multicolumn{2}{|c|}{ BOB leaf } & \multicolumn{2}{|c|}{ Filtration } \\
\hline & Phytophthora & Pythium & Phytophthora & Pythium & Phytophthora & Pythium \\
\hline Nursery 1 pond & 5 & 31 & 20 & 13 & 20 & 36 \\
\hline Nursery 2 pond & 7 & 8 & 12 & 3 & 8 & 18 \\
\hline Dungeness River & 6 & 2 & 7 & 1 & 10 & 12 \\
\hline Gierin Creek & 5 & 3 & 4 & 3 & 6 & 18 \\
\hline Total & 23 & 44 & 43 & 20 & 44 & 84 \\
\hline
\end{tabular}


Research has shown that the behavior and survival of $P$. ramorum zoospores are influenced by water temperature, $\mathrm{pH}$, and $\mathrm{EC}$. The temperature of water at the field sites was within the range of 10 to $30^{\circ} \mathrm{C}$ that supports sporangia production (Englander et al. 2006) and $<25^{\circ} \mathrm{C}$, where sporangia are likely to germinate directly rather than produce zoospores (Parke and Lucas 2008). Water pH values were found to be between $\mathrm{pH} 5.52$ and 7.79 for all water types. Kong et al. (2012b) reported an immediate $P$. ramorum zoospore survival rate of 79.3 and $100 \%$ for water with $\mathrm{pH} 5$ and 7, respectively; however, survival rates dropped to 20.9 and $39.9 \%$, respectively, after 24 h. Kong et al. (2012a) found that P. ramorum zoospores could survive over a wide range of EC values, including zero, and that higher EC values resulted in higher zoospore survival rates. EC of lab water was much lower than that of creek water; however, the lower EC of lab water did not result in fewer viable zoospores as measured by DP CFU when compared with filtration CFU in creek water trials. Similar to Kong et al. (2012b), survival rates dropped for all EC values after $24 \mathrm{~h}$ (Kong et al. 2012a). Zoospore survival rate was not investigated at $24 \mathrm{~h}$ or at the time of bait removal in this research.

DO and ORP readings were similar to mean values found for water in an irrigation runoff containment basin over a multiyear monitoring period (Hong et al. 2009). It is not well understood at this time how DO and ORP affect the survival of $P$. ramorum. Zoospores of $P$. nicotianae, $P$. tropicalis, $P$. megasperma, and $P$. pini had the highest survival rate at DO concentrations between 5.3 and $5.6 \mathrm{mg} / \mathrm{liter}$ but survival rate varied between species as DO concentrations increased or decreased (Kong and Hong 2014). Pythium dissotocum zoospores exposed to water with an ORP of $670 \mathrm{mV}$ had a mortality rate of 15 to $40 \%$ (Lang et al. 2008); however, the ORP was much lower for lab, creek, and nursery pond water. Further research is required to determine the behavior of Phytophthora ramorum zoospores exposed to DO and ORP values found in rivers, streams, and nursery irrigation ponds similar to the ones in this study.

$P$. ramorum was not recovered from N2, DR, and GC. Increasing the number of sampling dates to include late winter and spring, peak recovery times of $P$. ramorum (Murphy et al. 2008; Oak et al. 2013), may be necessary to detect the pathogen at these sites. Detection of $P$. ramorum by filtration may have been hindered by fast-growing Pythium and Phytophthora spp. that interfere with visual identification of $P$. ramorum on PARPH-V8 media (Reeser et al. 2011). P. ramorum recovery may be enhanced by filtering smaller aliquots of water to spread out the distribution of propagules among more filters (Reeser et al. 2011).

Isolates of $P$. citrophthora, commonly recovered from nursery effluent (Bush et al. 2003; MacDonald et al. 1994), and P. hydropathica were both identified at N2. $P$. hydropathica, a pathogen that causes leaf necrosis and shoot blight on Rhododendron catawbiense, has been recovered from irrigation reservoirs in Virginia and neighboring states during warm summer weather (Hong et al. 2010). P. hydropathica was molecularly identified on two pieces of symptomatic leaf tissue and visually identified according to Hong et al. (2010) as having chlamydospores with dense protoplasm and obovate hyphal swellings on approximately $44 \%$ of the isolates recovered from N2. Other species of Phytophthora in the pond, including $P$. hydropathica, may have been able to colonize bait material before $P$. ramorum (Sutton et al. 2009). Recovery of $P$. hydropathica is highest during hot summers and rapidly declines in cooler water temperatures (Hong et al. 2010). P. ramorum detection may be improved if baiting is done when pond water temperatures are lower.

In conclusion, baiting with rhododendron leaves, disks, and pear fruit along with filtration and $\mathrm{qPCR}$ methods detected $P$. ramorum zoospores with only minor differences in sensitivity between the types of water used. The data suggest that filtration and qPCR were equally effective in detecting a range of concentrations of $P$. ramorum zoospores and could provide information on zoospore density over 451 DP CFU/liter. Leaf disks were able to estimate zoospore density in lab and creek water up to $451 \mathrm{DP}$ CFU/liter while pear and wounded whole-leaf baits appeared to be better at detection than quantification of zoospore density.

\section{Acknowledgments}

This research was made possible with funding from the United States Department of Agriculture APHIS Cooperative Agreement 12-8130-0178-CA. Information on $P$. ramorum zoospore density in lab and stream water was provided by J. Hwang, Clemson University and S. Oak, United States Department of Agriculture Forest Service, Southern Region (retired). We thank the staff of the WSU Puyallup Ornamental Plant Pathology program at the Puyallup Research and Extension Center for their assistance.

\section{Literature Cited}

Bush, E. A., Hong, C. X., and Stromberg, E. L. 2003. Fluctuations of Phytophthora and Pythium spp. in components of a recycling irrigation system. Plant Dis. 87: 1500-1506.

Cao, Y., Griffith, J. F., Dorevitch, S., and Weisberg, S. B. 2012. Effectiveness of qPCR permutations, internal controls and dilution as means for minimizing the impact of inhibition while measuring Enterococcus in environmental waters. J. Appl. Microbiol. 113:66-75.

Chastagner, G., Coats, K., and Elliott, M. 2013. An overview of Phytophthora ramorum in Washington state. Pages 14-15 in: Proc. Sudden Oak Death Fifth Sci. Symp. S. J. Frankel, J. T. Kliejunas, K. M. Palmieri, and J. M. Alexander, tech. coords. U.S. Dep. Agric. For. Ser. Gen. Tech. Rep. PSWGTR-243. Albany, CA.

Chastagner, G., Oak, S., Omdal, D., Ramsey-Kroll, A., Coats, K., Valachovic, Y., Lee, C., Hwang, J., Jeffers, S., and Elliott, M. 2010. Spread of P. ramorum from nurseries into waterways-Implication for pathogen establishment in new areas. Pages 22-26 in: Proc. Sudden Oak Death Fourth Sci. Symp. S. J. Frankel, J. T. Kliejunas, and K. M. Palmieri, tech. coords. U.S. Dep. Agric. For. Ser. Gen. Tech. Rep. PSW-GTR-229. Albany, CA.

Clement, J. A. J., Baldwin, T. K., Magalon, H., Glais, I., Gracianne, C., Andrivon, D., and Jacquot, E. 2013. Specific detection and quantification of virulent/avirulent Phytophthora infestans isolates using a real-time PCR assay that targets polymorphisms of the Avr3a gene. Online. Lett. Appl. Microbiol. 56:322-332.

Colburn, G., and Jeffers, S. 2011. Use of real-time and nested PCR to detect Phytophthora ramorum in infested nursery container mixes and soils. (Abstr.) Phytopathology 101:S38

Cooke, D. E. L., Drenth, A., Duncan, J. M., Wagels, G., and Brasier, C. M. 2000. A molecular phylogeny of Phytophthora and related oomycetes. Fungal Genet. Biol. 30:17-32.

Davidson, J. M., Patterson, H. A., and Rizzo, D. M. 2008. Sources of inoculum for Phytophthora ramorum in a redwood forest. Phytopathology 98:860-866.

Davidson, J. M., Wickland, A. C., Patterson, H. A., Falk, K. R., and Rizzo, D. M 2005. Transmission of Phytophthora ramorum in mixed-evergreen forest in California. Phytopathology 95:587-596.

Dolezel, J., Bartos, J., Voglmayr, H., and Greilhuber, J. 2003. Nuclear DNA content and genome size of trout and human. Cytometry 51A:127-128.

Englander, L., Browning, M., and Tooley, P. W. 2006. Growth and sporulation of Phytophthora ramorum in vitro in response to temperature and light. Mycologia 98:365-373.

Erwin, D. C., and Ribeiro, O. K. 1996. Phytophthora Diseases Worldwide. American Phytopathological Society, St. Paul, MN.

Ferguson, A. J., and Jeffers, S. N. 1999. Detecting multiple species of Phytophthora in container mixes from ornamental crop nurseries. Plant Dis. 83:1129-1136.

Frankel, S. J. 2008. Sudden oak death and Phytophthora ramorum in the USA: A management challenge. Australas. Plant Pathol. 37:19-25.

Hao, W., Ahonsi, M. O., Vinatzer, B. A., and Hong, C. 2012. Inactivation of Phytophthora and bacterial species in water by a potential energy-saving heat treatment. Eur. J. Plant Pathol. 134:357-365.

Hayden, K., Ivors, K., Wilkinson, C., and Garbelotto, M. 2006. TaqMan chemistry for Phytophthora ramorum detection and quantification, with a comparison of diagnostic methods. Phytopathology 96:846-854

Hayden, K. J., Rizzo, D., Tse, J., and Garbelotto, M. 2004. Detection and quantification of Phytophthora ramorum from California forests using a realtime polymerase chain reaction assay. Phytopathology 94:1075-1083.

Hong, C. X., Gallegly, M. E., Richardson, P. A., Kong, P., Moorman, G. W. Lea-Cox, J. D., and Ross, D. S. 2010. Phytophthora hydropathica, a new pathogen identified from irrigation water, Rhododendron catawbiense and Kalmia latifolia. Plant Pathol. 59:913-921.

Hong, C. X., Lea-Cox, J. D., Ross, D., Moorman, G. W., Richardson, D. S., Ghimire, S. R., and Kong, P. 2009. Containment basin water quality fluctuation and implications for crop health management. Irrig. Sci. 27:485-496.

Hong, C. X., and Moorman, G. W. 2005. Plant pathogens in irrigation water: Challenges and opportunities. Crit. Rev. Plant Sci. 24:189-208.

Hong, C. X., Richardson, P. A., and Kong, P. 2002. Comparison of membrane filters as a tool for isolating pythiaceous species from irrigation water. Phytopathology 92:610-616.

Hughes, K. J. D., Tomlinson, J. A., Griffin, R. L., Boonham, N., Inman, A. J., and Lane, C. R. 2006. Development of a one-step real-time polymerase chain reaction assay for diagnosis of Phytophthora ramorum. Phytopathology 96: 975-981.

Hwang, J., Oak, S. W., and Jeffers, S. N. 2008. Detecting Phytophthora ramorum and other species of Phytophthora in streams in natural ecosystems using 
baiting and filtration methods. Page 55-58 in: Proc. Sudden Oak Death Third Sci. Symp. S. J. Frankel, J. T. Kliejunas, and K. M. Palmieri, tech. coords. U.S. Dep. Agric. For. Ser. Gen. Tech. Rep. PSW-GTR-214. Albany, CA.

Jeffers, S. N., Hwang, J., Wamishe, Y. A., and Oak, S. W. 2010. Detection of Phytophthora ramorum at retail nurseries in the southeastern United States. Pages 69-71 in: Proc. Sudden Oak Death Fourth Sci. Symp. S. J. Frankel, J. T. Kliejunas, and K. M. Palmieri, tech. coords. U.S. Dep. Agric. For. Ser. Gen. Tech. Rep. PSW-GTR-229. Albany, CA.

Judelson, H. S., and Blanco, F. A. 2005. The spores of Phytophthora: Weapons of the plant destroyer. Nat. Rev. Microbiol. 3:47-58.

Kong, P., and Hong, C. X. 2014. Oxygen stress reduces zoospore survival of Phytophthora species in a simulated aquatic system. BMC Microbiol. 14:124.

Kong, P., Lea-Cox, J. D., and Hong, C. X. 2012a. Effect of electrical conductivity on survival of Phytophthora alni, P. kernoviae and P. ramorum in a simulated aquatic environment. Plant Pathol. 61:1179-1186.

Kong, P., Lea-Cox, J. D., Moorman, G. W., and Hong, C. X. 2012b. Survival of Phytophthora alni, Phytophthora kernoviae, and Phytophthora ramorum in a simulated aquatic environment at different levels of $\mathrm{pH}$. FEMS Microbiol. Lett. 332:54-60.

Kreader, C. A. 1996. Relief of amplification inhibition in PCR with bovine serum albumin or T4 gene 32 protein. Appl. Environ. Microbiol. 62:1102-1106.

Lang, J. M., Rebits, B., Newman, S. E., and Tisserat, N. 2008. Monitoring mortality of Pythium zoospores in chlorinated water using oxidation reduction potential. Online publication. Plant Health Prog doi:10.1094/PHP2008-0922-01-RS

Lefèvre, E., Jobard, M., Venisse, J. S., Bec, A., Kagami, M., Amblard, C., and SimeNgando, T. 2010. Development of a real-time PCR assay for quantitative assessment of uncultured freshwater zoosporic fungi. J. Microbiol. Methods 81:69-76.

Loyd, A. L., Benson, D. M., and Ivors, K. L. 2014. Phytophthora populations in nursery irrigation water in relationship to pathogenicity and infection frequency of Rhododendron and Pieris. Plant Dis. 98:1213-1220.

MacDonald, J. D., Alishtayeh, M. S., Kabashima, J., and Stites, J. 1994. Occurrence of Phytophthora species in recirculated nursery irrigation effluents. Plant Dis. 78:607-611.

Murphy, S., Lee, C., Valachovic, Y., Bienapfl, J., Mark, W., Jirka, A., Owen, D. R., Smith, T. F., and Rizzo, D. M. 2008. Monitoring Phytophthora ramorum distribution in streams within California watersheds. Pages 409-411 in: Proc. Sudden Oak Death Third Sci. Symp. S. J. Frankel, J. T. Kliejunas, and K. M. Palmieri, tech. coords. U.S. Dep. Agric. For. Ser. Gen. Tech. Rep. PSW-GTR-214. Albany, CA.

Nutz, S., Doll, K., and Karlovsky, P. 2011. Determination of the LOQ in real-time PCR by receiver operating characteristic curve analysis: Application to qPCR assays for Fusarium verticillioides and $F$. proliferatum. Anal. Bioanal. Chem. 401:717-726.

Oak, S. 2014. 2013 National Phytophthora ramorum early detection survey summary report. Visualizing Sudden Oak Death e-Conference. COMTF. Online publication. http://www.suddenoakdeath.org/wp-content/uploads/2014/01/Oak-EarlyDetection-Survey-Summary-Report-SOD-Webinar-2014.pdf

Oak, S., Hwang, J., and Jeffers, S. 2013. Comparison of in situ and in vitro baiting assays for Phytophthora ramorum survey of waterways in the southeastern United States. Pages 51-52 in: Proc. Sudden Oak Death Fifth Sci. Symp. S. J. Frankel, J. T. Kliejunas, K. M. Palmieri, and J. M. Alexander, tech. coords. U.S. Dep. Agric. For. Ser. Gen. Tech. Rep. PSW-GTR-243. Albany, CA.

Opel, K. L., Chung, D., and McCord, B. R. 2010. A study of PCR inhibition mechanisms using real-time PCR. J. Forensic Sci. 55:25-33.

Parke, J. L., and Lucas, S. 2008. Sudden oak death and ramorum blight. Online publication. Plant Health Instruct. doi:10.1094/PHI-I-2008-0227-01

Raith, M. R., Ebentier, D. L., Cao, Y., Griffith, J. F., and Weisberg, S. B. 2014. Factors affecting the relationship between quantitative polymerase chain reaction (qPCR) and culture-based enumeration of Enterococcus in environmental waters. J. Appl. Microbiol. 116:737-746.

Reeser, P. W., Sutton, W., Hansen, E. M., Remigi, P., and Adams, G. C. 2011. Phytophthora species in forest streams in Oregon and Alaska. Mycologia 103:22-35.

Rizzo, D. M., and Garbelotto, M. 2003. Sudden oak death: Endangering California and Oregon forest ecosystems. Front. Ecol. Environ 1:197-204.
Sanzani, S. M., Nicosia, M., Faedda, R., Cacciola, S. O., and Schena, L. 2014. Use of quantitative PCR detection methods to study biocontrol agents and phytopathogenic fungi and oomycetes in environmental samples. J. Phytopathol. 162:1-13.

Scibetta, S., Schena, L., Chimento, A., Cacciola, S. O., and Cooke, D. E. L. 2012 A molecular method to assess Phytophthora diversity in environmental samples. J. Microbiol. Methods 88:356-368.

Sechler, K. E., Colburn, G. C., and Shishkoff, N. 2006. Detection of Phytophthora ramorum chlamydospores in soil using real-time PCR. (Abstr.) Phytopathology 96:S191.

Sutton, W., Hansen, E. M., Reeser, P. W., and Kanaskie, A. 2009. Stream monitoring for detection of Phytophthora ramorum in Oregon tanoak forests. Plant Dis. 93:1182-1186.

Tjosvold, S., Chambers, D., and Fichtner, E. 2010. Importance of rainfall and sprinkler irrigation in supporting sporulation, spread of inoculum in runoffwater, and new infections of Phytophthora ramorum under field conditions. Pages 76-77 in: Proc. Sudden Oak Death Fourth Sci. Symp. S. J. Frankel, J. T. Kliejunas, and K. M. Palmieri, tech. coords. U.S. Dep. Agric. For. Ser. Gen. Tech. Rep. PSW-GTR-229. Albany, CA.

Tjosvold, S., Chambers, D., Koike, S., and Mori, S. 2008. Disease on nursery stock as affected by environmental factors and seasonal inoculum levels of Phytophthora ramorum in stream water used for irrigation. Plant Dis. 92: 1566-1573.

Tyler, B. M., Tripathy, S., Zhang, X. M., Dehal, P., Jiang, R. H. Y., Aerts, A., Arredondo, F. D., Baxter, L., Bensasson, D., Beynon, J. L., Chapman, J., Damasceno, C. M. B., Dorrance, A. E., Dou, D. L., Dickerman, A. W., Dubchak, I. L., Garbelotto, M., Gijzen, M., Gordon, S. G., Govers, F., Grunwald, N. J., Huang, W., Ivors, K. L., Jones, R. W., Kamoun, S., Krampis, K., Lamour, K. H., Lee, M. K., McDonald, W. H., Medina, M., Meijer, H. J. G., Nordberg, E. K., Maclean, D. J., Ospina-Giraldo, M. D. Morris, P. F., Phuntumart, V., Putnam, N. H., Rash, S., Rose, J. K. C., Sakihama, Y., Salamov, A. A., Savidor, A., Scheuring, C. F., Smith, B. M. Sobral, B. W. S., Terry, A., Torto-Alalibo, T. A., Win, J., Xu, Z. Y., Zhang, H. B., Grigoriev, I. V., Rokhsar, D. S., and Boore, J. L. 2006. Phytophthora genome sequences uncover evolutionary origins and mechanisms of pathogenesis. Science 313:1261-1266.

USDA-APHIS PPQ. 2013. Quantitative multiplex real-time PCR (qPCR) for detection of Phytophthora ramorum (ITS target) using a TaqMan system on the Cepheid SmartCycler ${ }^{(B)}$ and the ABI 7900/7000. WI-B-T-1-6 revision 7. Online publication. United States Department of Agriculture Animal and Plant Health Inspection Service, Plant Protection and Quarantine. https://www.aphis.usda. gov/plant_health/plant_pest_info/pram/downloads/pdf_files/DiagnosticsTable.pdf

USDA-APHIS PPQ. 2014. Water sampling protocol. 2013 Phytophthora ramorum Nursery Survey, appendix 7. Online publication. United States Department of Agriculture Animal and Plant Health Inspection Service, Plant Protection and Quarantine. https://www.aphis.usda.gov/plant_health/plant_pest_info/pram/ downloads/surveyplan/appendixI.pdf

U.S. Environmental Protection Agency. 2010. Method A: Enterococci in Water by TaqMan Quantitative Polymerase Chain Reaction (qPCR) Assay. EPA-821-R10-004. Office of Water, Washington, DC.

U.S. EPA. 2012. Guidelines for Water Reuse. 600/R-12/618. United States Environmental Protection Agency, Washington, DC.

Werres, S., Marwitz, R., Veld, W., De Cock, A., Bonants, P. J. M., De Weerdt, M. Themann, K., Ilieva, E., and Baayen, R. P. 2001. Phytophthora ramorum sp. nov., a new pathogen on Rhododendron and Viburnum. Mycol. Res. 105: $1155-1165$

Werres, S., Wagner, S., Brand, T., Kaminski, K., and Seipp, D. 2007. Survival of Phytophthora ramorum in recirculating irrigation water and subsequent infection of Rhododendron and Viburnum. Plant Dis. 91:1034-1044.

White, T. J., Bruns, T., Lee, S., and Taylor, J. 1990. Amplification and direct sequencing of fungal ribosomal RNA genes for phylogenetics. Pages 315-322 in: PCR Protocols: A Guide to Methods and Applications. M. A. Innis, D. H. Gelfand, J. J. Sninsky, and T. J. White, eds. Academic Press, San Diego, CA.

Zhang, Z. G., Li, Y. Q., Fan, H., Wang, Y. C., and Zheng, X. B. 2006. Molecular detection of Phytophthora capsici in infected plant tissues, soil and water. Plant Pathol. 55:770-775. 